\title{
Physiological performance of açai seeds (Euterpe oleracea Mart.) stored with different moisture contents and treated with fungicide ${ }^{1}$
}

\author{
Juliana Maria Espíndola Lima ${ }^{2}$, João Almir Oliveira², Oscar José Smiderle ${ }^{3}$, \\ André Vitor Carvalho Lousado ${ }^{2}$, Maria Laene Moreira de Carvalho
}

\begin{abstract}
The expansion of açai production has increased the importance of management of seeds used for replanting or expanding the plantation areas. Thus, the aim of this work was to evaluate the performance of açai seeds with different moisture contents, treated or untreated with fungicide, and stored for 180 days. The seeds were divided into three moisture levels (35\%,30\% and $20 \%)$, and with or without fungicide treatment, with four storage evaluation periods $(0,60,120$ and 180 days). They were packed in plastic bags and kept in natural environment. The experimental design was completely randomized, with a $3 \times 2 \times 4$ factorial scheme (moisture contents $\mathrm{x}$ treated or untreated with fungicide $\mathrm{x}$ period of evaluation), with four replications of 50 seeds each. The following tests were conducted: moisture content, germination, tetrazolium test, seedling emergence, seedling emergence speed and X-ray. Açai seeds with $35 \%$ and $30 \%$ moisture contents treated with fungicide showed a better physiological quality in relation to the untreated ones. Storage longer than 120 days reduced seed germination to values below $50 \%$, regardless of whether they were treated or not with fungicide, although the reduction was greater in untreated seeds. The fungicide treatment is efficient in controlling fungi in açai seeds with $30 \%$ and $20 \%$ moisture content for up to 180 days of storage, and in seeds with $35 \%$ moisture content for up to 60 days of storage.
\end{abstract}

Index terms: recalcitrant seed, drying, viability.

\section{Desempenho fisiológico de sementes de açaí (Euterpe oleracea Mart.) armazenadas com diferentes teores de água e tratadas com fungicida}

\begin{abstract}
RESUMO - Com a expansão da produção de açaí, os cuidados com o manejo das sementes utilizadas para replantio ou aumento de área de cultivo se tornaram importantes. Objetivou-se avaliar o desempenho de sementes de açaí com diferentes teores de água e armazenadas com e sem tratamento fungicida por 180 dias. As sementes de açaí foram separadas por graus de umidade $(35 \%, 30 \%$ e $20 \%)$ e tratadas ou não com fungicida, com quatro épocas de avaliação do armazenamento $(0,60,120$ e 180 dias $)$ em ambiente natural. O delineamento experimental foi inteiramente ao acaso, com arranjo fatorial 3 x 2 × 4 (graus de umidade $\mathrm{x}$ com e sem fungicida x épocas de avaliação), com quatro repetições de 50 sementes. As sementes foram avaliadas quanto ao grau de umidade, germinação, teste de tetrazólio, emergência de plântulas, velocidade de emergência de plântulas e raio-X. As sementes de açaí com $30 \%$ e $35 \%$ de grau de umidade tratadas com fungicida tiveram melhor qualidade fisiológica em relação às sementes sem tratamento fungicida. $\mathrm{O}$ armazenamento com duração superior a 120 dias reduziu a germinação das sementes para valores abaixo de 50\%, independentemente de estarem com ou sem fungicida, porém a redução foi maior para as sementes sem tratamento fungicida. O tratamento com fungicida é eficiente no controle de fungos até 180 dias de armazenamento, para as sementes de açaí com $30 \%$ e $20 \%$ de grau de umidade, e até 60 dias, para as sementes com $35 \%$ de grau de umidade.
\end{abstract}

Termos de indexação: semente recalcitrante, secagem, viabilidade.

\section{Introduction}

The palm tree Euterpe oleracea Mart., popularly known as açai, has garnered attention due to the expansion of the

${ }^{1}$ Submitted on 08/16/2017. Accepted for publication on 01/16/2018.

${ }^{2}$ Universidade Federal de Lavras, 37.200-000 - Lavras, MG, Brasil. fruit pulp and the palm heart commerce, which is extremely important to the Amazon region (Nascimento et al., 2010; Nascimento and Moraes, 2011). Over the years, açai has gained national and international market due to the caloric

${ }^{3}$ Embrapa, Distrito Industrial, Cx. Postal 133, 69301-970, Boa Vista, RR, Brasil. *Corresponding author<espindolaj5@hotmail.com> 
value of its pulp. It is rich in proteins, fiber, lipids, vitamin $\mathrm{E}$ and minerals (manganese, copper, boron and chromium), besides being a considerable source of energy.

With the expansion of açai production, the management of seeds used to replant or expand the plantation area became more important, because this is the most usual form of propagation of the species. It presents recalcitrant seeds, that is, seeds that are intolerant to desiccation (Barbedo and Marcos-Filho, 1998).

Intolerance to desiccation makes the storage of seeds for later use more difficult, because the function of storage is to preserve the physiological and biochemical qualities of seeds for as long as possible. Conversely, recalcitrant seeds lose their viability very rapidly during storage due to their moisture content. In recalcitrant seeds, one of the main problems observable even in short periods of storage is the need for high relative humidity and high seed moisture, in order to maintain viability. This is how conservation is generally done. However, this type of storage causes proliferation of microorganisms, which favors deterioration, reducing vigor or causing the death of the seeds (Berjak, 1995; Nascimento and Moraes, 2011).

Quality deterioration of recalcitrant seeds due to fungal incidence has been little studied, but some works already showed that non-infested and disinfested seeds had an extended viability compared to the infested ones (Berjak, 1995; Mittal, 2003; Oliveira et al., 2011; Parisi et al., 2013).

In this context, a possible strategy is to use fungicides for treating the seeds, such as carbedazim, carboxin, captan, thiabendazole and thiram (Bonome et al., 2009; Krugner and Auer, 2005). Once applied, these products protect the seeds against fungal attack, maintaining the sanitary quality during storage, and preventing fungi from affecting the physiological quality of the seeds. Many fungal disease agents can be transmitted and disseminated by seeds, and the use of fungicides aims to control these pathogens, and to protect seedlings at a low cost (Balardin et al., 2011; Pereira et al., 2011).

Then, due to the difficulties of dealing with recalcitrant seeds, which require adequate processing and storage conditions, the use of fungicides can reduce the loss caused by fungi, since these seeds need to be stored with high moisture contents. So, the objective of this study was to evaluate the physiological performance of açai seeds with three different moisture contents, treated or untreated with fungicide and stored for 180 days.

\section{Material and Methods}

Açai berries (E. oleracea) were collected in their native environment, in the city of Anori, located in the Brazilian state of Amazonas (AM) (346’24'S latitude, 61038'40"W longitude). The collections were conducted in January 2014, and the berries were sent to the seed sector of the Embrapa Roraima, city of Boa Vista, state of Roraima (RR), where they were pulped. Further on, the samples were sent to the Universidade Federal de Lavras (UFLA). The evaluation of the physical and physiological qualities of the seeds was managed by the central seed laboratory of UFLA, in the city of Lavras, located in the state of Minas Gerais (MG).

The berries were mechanically pulped, and then the seeds were washed until they were clean. Their initial moisture content was $42 \%$, so they were put inside greenhouse, at room temperature $\left(30-34{ }^{\circ} \mathrm{C}\right)$ to slow dry until they reached $30 \%$ moisture content (reached in five days), which would be the minimum drying limit for this species, according to Nascimento et al. (2007). This moisture content was chosen, so the seeds would not arrive at destination with a high respiration rate caused by high moisture. This would potentially cause microorganism proliferation and losses.

The seeds were selected according to the average dimensions of $9.45 \mathrm{~mm}$ length and $10.62 \mathrm{~mm}$ width (large seeds). After that, they were packed in plastic bags and stowed in polystyrene foam sealed boxes to avoid gain or loss of moisture. A germination test was then carried out, using sterilized sand as substrate when seeds were $42 \%$ moisture content. The count was performed 90 days after the experiment setting, and an outcome of $91 \%$ germination rate was obtained. This test was performed only to verify the initial quality of the seeds and to check if there had been any quality loss during transportation.

The temperature inside the polystyrene foam boxes was measured $\left(24-25^{\circ} \mathrm{C}\right)$, and the moisture content was established as proposed in the Rules for Seed Testing (Brasil, 2009). The obtained result was similar to the moisture content after the drying process $(30 \%)$. Regarding the seeds, it took three days for the packages to arrive at UFLA, and after initial verification at the reception, the lot was divided into three sample groups to form three different moisture content treatments. This allowed the verifying of efficiency of the fungicide in controlling fungi throughout the storage process.

Sample 1 seeds were submerged in distilled water (replaced every 24 hours), and kept in germinator at $25^{\circ} \mathrm{C}$, until they reached $35 \%$ moisture content (taking four days). Water immersion technique was chosen because the seeds have a thick tegument and do not absorb water easily. Sample 2 seeds were kept with $30 \%$ moisture content, and sample 3 seeds were dried in air-circulating oven at $25^{\circ} \mathrm{C}$, until reached $20 \%$ moisture content (at five days' time).

The drying method in wet basis (w.b.) was used, according to Carvalho (2005), and the water gain and seed drying were 
monitored by weighing the seeds during the process and using the following formula:

$$
\begin{aligned}
& \mathrm{W}_{\mathrm{f}}\left(100-\mathrm{MC}_{\mathrm{f}}\right)=\mathrm{W}_{\mathrm{i}}\left(100-\mathrm{MC}_{\mathrm{i}}\right) \\
& \mathrm{W}_{\mathrm{f}}: \text { Final weight } \\
& \mathrm{MC}_{\mathrm{f}}: \text { Final moisture content } \\
& \mathrm{W}_{\mathrm{i}} \text { : Initial weight } \\
& \mathrm{MC}_{\mathrm{i}}: \text { Initial moisture content }
\end{aligned}
$$

After weighting, the moisture content of the seeds was determined for each sample (35\% and $20 \%$ ) to guarantee that seeds had the desired condition. In all cases, the methodology described in the Rules for Seed Testing (Brasil, 2009) was used $\left(105 \pm 3{ }^{\circ} \mathrm{C}\right.$, w.b. $)$.

After the moistening and drying procedures, the seeds were subdivided again. One subsample was treated with the fungicide Vitavax Thiran, in the proportion of $250 \mathrm{~mL} / 100 \mathrm{~kg}$ of seeds, and the other remained untreated and served as a control treatment.

Both treated and untreated subsamples were divided into four other samples to study the storage periods $(0,60,120$ and 180 days). The seeds were ultimately packed in semipermeable transparent plastic bags $(20 \mathrm{~cm}$ width $\mathrm{x} 30 \mathrm{~cm}$ length $\mathrm{x} 0.13$ $\mathrm{mm}$ thickness), which were sealed. They were then stored at room temperature and ambient relative humidity, and monitored throughout the experiment (Figure 1). The experimental design was completely randomized with a $3 \times 2 \times 4$ factorial scheme (three moisture contents $\mathrm{x}$ treated or untreated with fungicide $\mathrm{x}$ four evaluation periods), with four replications of 50 seeds each.

To determine the physical and physiological qualities of the açai seeds with different moisture contents, treated or not with fungicide, the following tests were carried out:

Moisture content (w.b.): for each treatment, four replications were performed. The seeds were cut into pieces smaller than $7.0 \mathrm{~mm}$, and each replication corresponded to the weight of five whole seeds. The samples were put in the oven at $105^{\circ} \mathrm{C} \pm 3{ }^{\circ} \mathrm{C}$ for 24 hours, according to Brasil (2009). The results were expressed as percentage.

Germination: four replications with 50 seeds were performed for each treatment. The seeds were placed on germitest paper, moistened with distilled water in the proportion of 2.5 times the dry paper weight (Brasil, 2009). The paper rolls were kept inside germinator at $30^{\circ} \mathrm{C}$ for up to 90 days, and normal seedlings counts were carried out every seven days. In the end of the test, the sum of the counts was expressed as percentage. The seedlings that exhibited primary root emission and aerial part larger than $2 \mathrm{~cm}$ from the germinal button (adjacent germination) were considered normal.

Tetrazolium test: four replications of 50 seeds were performed, and a small cut was made on the side of each seed to improve water absorption. The seeds were put to soak distilled water and kept in BOD (Biochemical Oxygen Demand) incubator at $25{ }^{\circ} \mathrm{C}$ for 24 hours. After that, a transversal cut on the seeds' raphe line was made. Only one half of each seed (endosperm and embryo) was let to imbibe in $1 \%$ tetrazolium

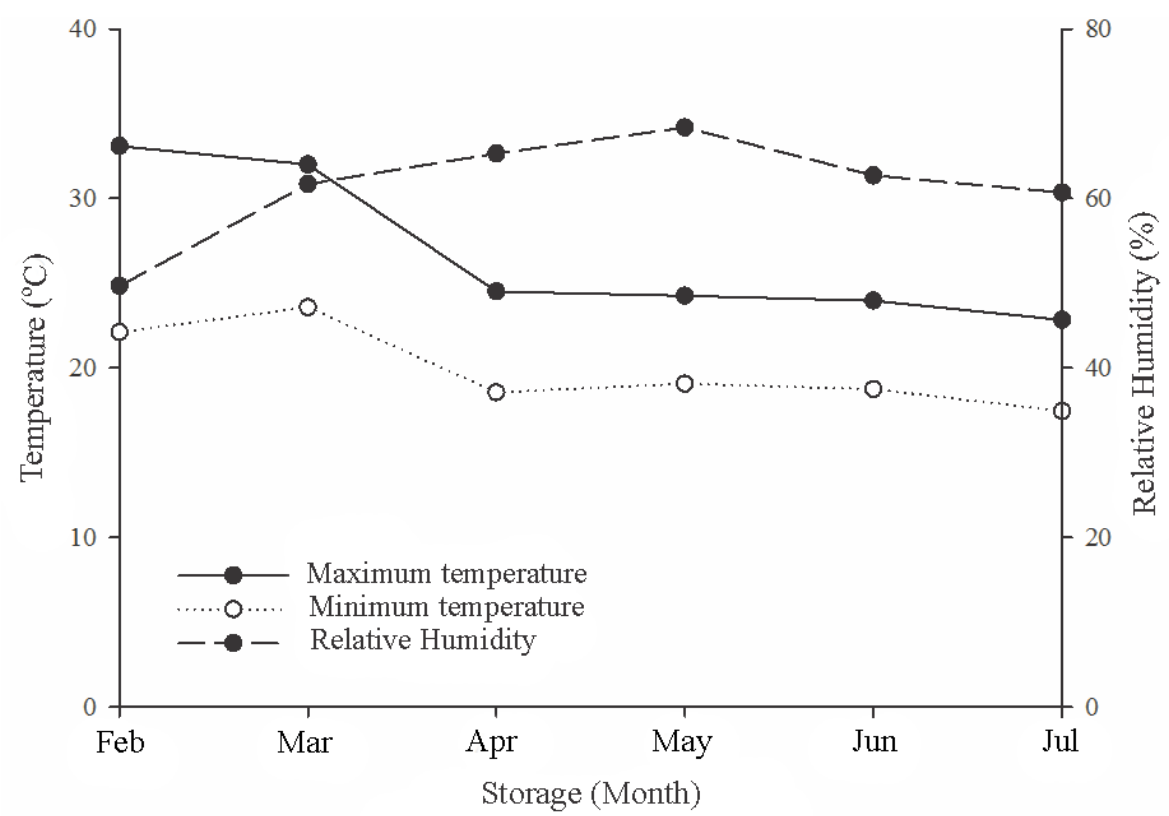

Figure 1. Maximum and minimum temperatures $\left({ }^{\circ} \mathrm{C}\right)$ and relative air humidity $(\mathrm{RH}, \%)$ during room-temperature storage of açai seeds. 
solution inside BOD, at a constant temperature of $30^{\circ} \mathrm{C}$ for 24 hours. The seeds were considered viable or unviable based on their color: viable seeds displayed colors from light to intense red, whereas unviable seeds showed colors from dark red to black or white (Figure 2). The results were expressed as percentage of viable seeds. Since no specific methodology for açai seeds was found in the literature, the tetrazolium test was performed considering the difficulty of water absorption during seeds moistening to $35 \%$ water content. Despite the existence of time variations, temperature and concentration were not assessed. Therefore, the applied method was successful for seed coloration.

Seedling emergence: four replications of each treatment were carried out, each one containing 50 seeds. They were sowed at $3 \mathrm{~cm}$ depth in plastic trays $(45 \mathrm{~cm}$ length $\mathrm{x} 20$ $\mathrm{cm}$ width $\times 10 \mathrm{~cm}$ depth) containing a $2: 1$ combination of gully soil and sand. The trays were maintained in a growth chamber at $30^{\circ} \mathrm{C}$, and the count of normal emerged seedlings was performed daily, up until 90 days. The results were expressed as percentage.

Seedlings emergence speed: it was assessed together with the seedling emergence test, by counting the number of emerged seedlings daily. The index was calculated by summing the number of daily-emerged seedlings, and dividing it by the number of days passed from sowing to emergence (Maguire, 1962).

$X$-ray: four replications of 50 seeds were used. The seeds were placed on a polystyrene sheet with cavities, and then put in a Faxitron X-Ray machine, preset for radiation intensity (24 Kvp) and exposure time (14 s). The radiographies were evaluated according to the number of undamaged whole seeds, and the results expressed as percentage.

After obtaining the results, the statistical analyses were performed with the software SISVAR (Ferreira, 2011). They included the analysis of variation, comparison of means at $5 \%$ significance by the Tukey's test, and the regression analysis with coefficient of determination and significance of $1 \%$ by the T-test.

\section{Results and Discussion}

Significant interactions between moisture content $\mathrm{x}$ storage (Figure 3A) and fungicide $\mathrm{x}$ storage (Figure 3B) were observed. Despite the fact that the seeds were stored in an uncontrolled environment (Figure 1), which may have led to a more intense water exchange between them and the environment due to higher temperature and relative humidity (RH) oscillations, the variation observed during storage stayed below two percentage points, when the lowest and the highest moisture contents reached by seeds were compared. The only exception were the seeds with $30 \%$ moisture content, which reached the highest variation of 2.36 percentage points.

For the seeds with $35 \%$ moisture content, the maximum and the minimum values, which significantly differed from each other, were $35.72 \%$ (120 days) and $34.29 \%$ (60 days). Seeds with $30 \%$ moisture content showed maximum and minimum values of $31.89 \%$ (180 days) and $29.53 \%$ (120 days); while for seeds with $20 \%$ moisture content, the values were $20.78 \%$ ( 60 days) e $19.73 \%$ (120 days).

In the interaction fungicide $\mathrm{x}$ storage (Figure $3 \mathrm{~B}$ ), a greater significant water gain was observed in the end of storage (120 and 180 days) for seeds treated with fungicide $(28.63 \%$ and $29.70 \%)$, when compared with the control treatment $(28.02 \%$ and $28.62 \%$, respectively). However, since it was low, this increase did not affect directly the physiological quality of the seeds.

This oscillation in moisture content of the seeds happened because the semipermeable packaging allowed water exchange between the seeds and the environment, as verified in this study and also by Brasileiro et al. (2011) for loquat seeds $\left(59 \%\right.$ moisture content), stored at $8{ }^{\circ} \mathrm{C}$ in paper and plastic bags for 180 days. These authors verified a gradual

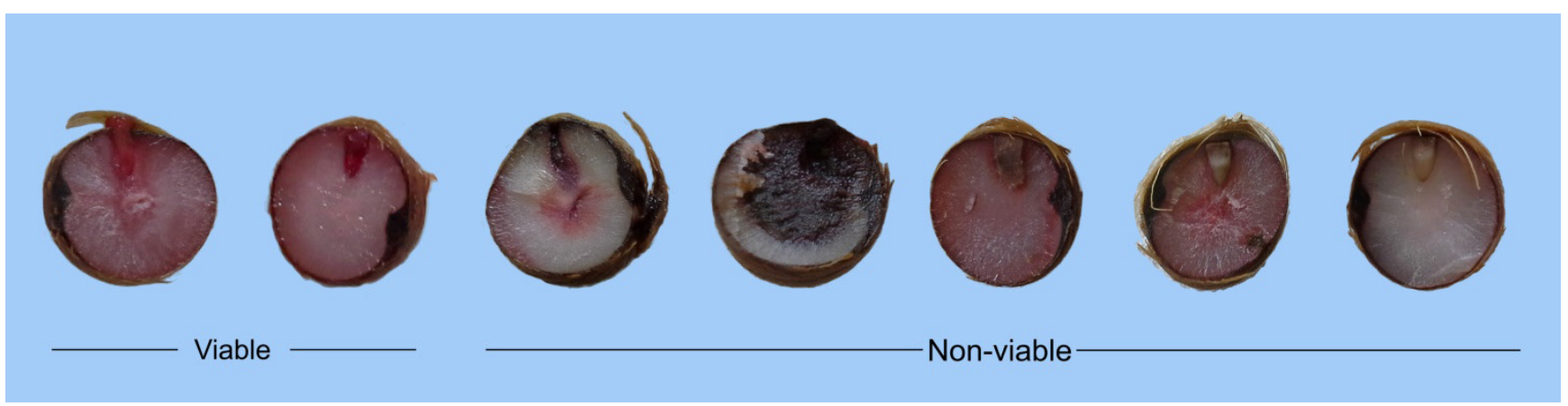

Figure 2. Classification of açai seeds into viable (light to intense red) and non-viable (dark red to black, or white) according to the tetrazolium test. 

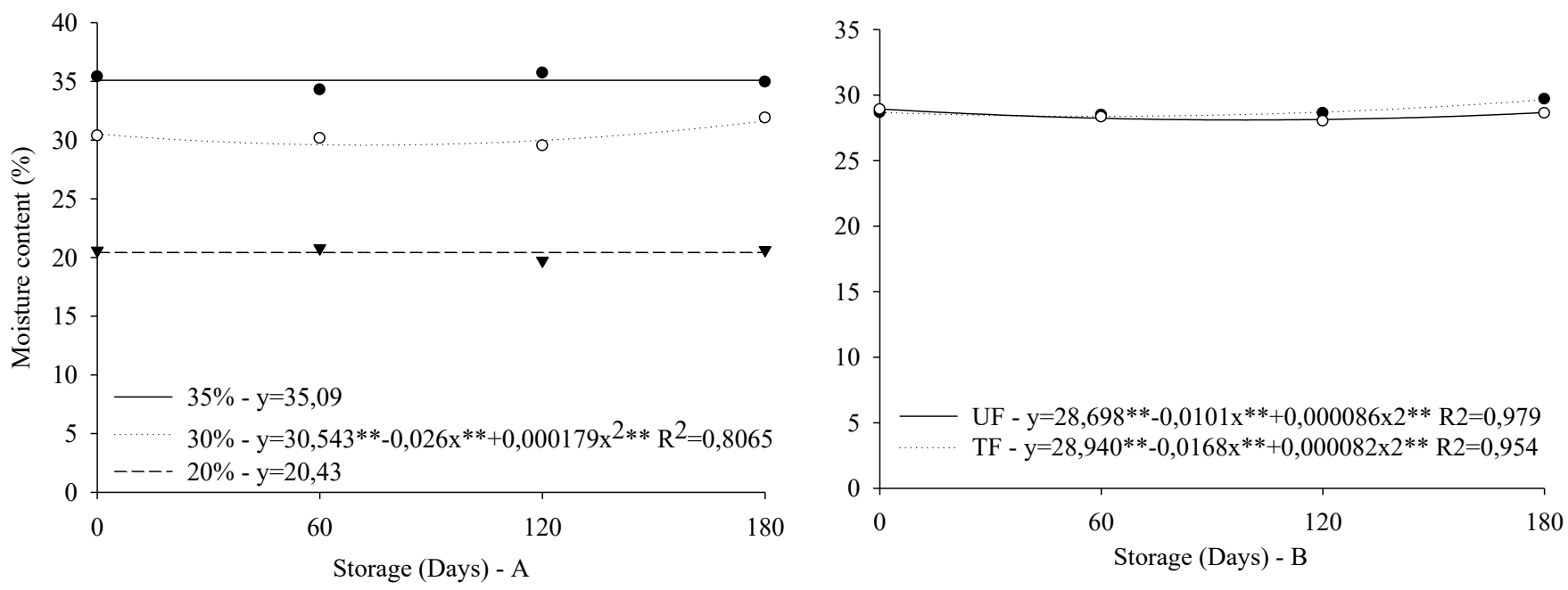

Figure 3. Mean values of the moisture content of açai seeds with different moisture contents $(35 \%-\bullet, 30 \%-\circ$ e $20 \%$ - $\mathbf{\nabla})(\mathrm{A})$, treated (TF - • ) and untreated (UF - $\circ$ ) with fungicide (B) and stored for 0, 60, 120 and 180 days.

**Significant at $1 \%$ according to the $\mathrm{T}$-test.

reduction in moisture content of seeds packed in paper bags, and a small variation in those kept in plastic bags. Nascimento and Moraes (2011) also observed a variation in moisture content during storage at $20^{\circ} \mathrm{C}$ for 360 days of E. oleracea (BRS Pará) seeds packed in paper bags, and with moisture content similar to the seeds used in this work.

The açai seeds germination data showed interaction between the factors moisture content $\mathrm{x}$ storage (Figure 4) and moisture content $\mathrm{x}$ fungicide (Table 1). In the beginning of the storage (day 0 ), the seeds with $35 \%$ and $30 \%$ moisture contents displayed the highest germination percentages $(81 \%$ and $83 \%$, respectively), while the seeds with $20 \%$ moisture content presented $15 \%$ germination. A greater uniformity in germination was observed in seeds with $35 \%$ moisture, caused by the imbibition period used, which may have helped to break seed dormancy, accelerating the germination process. Guedes et al. (2014) used different durations of imbibition in water to break açai seed dormancy and also obtained a reduction in the germination period and a greater uniformity. Therefore, performing the imbibition before sowing is an alternative to accelerate the germination of açai seeds.

The germination test performed when seeds were with $42 \%$ moisture content ( $91 \%$ outcome) showed that, during transportation, there was a reduction of about $10 \%$, in comparison with the germination and other tests realized during the first stages, which presented results above $80 \%$. Therefore, the transportation did not compromise the realization of the study.

After 60 days of storage, the seeds with $30 \%$ moisture content showed a germination of $76 \%$, which represents a lower reduction than that observed in the seeds with other moisture contents $(52 \%$ and $5 \%$ germination in seeds with $35 \%$ and $20 \%$ moisture contents, respectively).

The reductions that occurred from the first to the second germination stages were of 29.7 and 9 percentage points for the seeds carrying $35 \%, 30 \%$ and $20 \%$ moisture contents, respectively. Due to this greater reduction in the seeds with $35 \%$ moisture content, it is not recommended, for storage purposes, to remoisten seeds to maintain their moisture content above the tolerated limit proposed by Nascimento et al. (2007), because this accelerates the deterioration process.

Seeds moistening before sowing should be done only with the objective to obtain a greater uniformity in germination, as it was observed on the day 0 (Figure 4). After 120 and 180 days of storage, the germination rate was lower than $50 \%$ in seeds with $35 \%$ and $30 \%$ water contents, and $0 \%$ in seeds with $20 \%$ moisture content.

The second interaction (Table 1) showed that the seeds with $35 \%$ and $30 \%$ moisture contents treated with fungicide presented a germination percentage greater than the untreated ones. However, no significant difference was detected in seeds with $20 \%$ moisture content, regardless of the fungicide treatment. This can be justified by the sharp reduction in seed quality due to the drying process.

The efficiency of fungicide treatment in recalcitrant seeds was also studied by Brasileiro et al. (2011), who observed a germination rate above $80 \%$ in recalcitrant loquat seeds treated with the fungicide Captan, and stored in paper bags at $8^{\circ} \mathrm{C}$ for 180 days. Oliveira et al. (2011) worked with grumixameira, pitangueira and uvaiera seeds packed in plastic bags and 


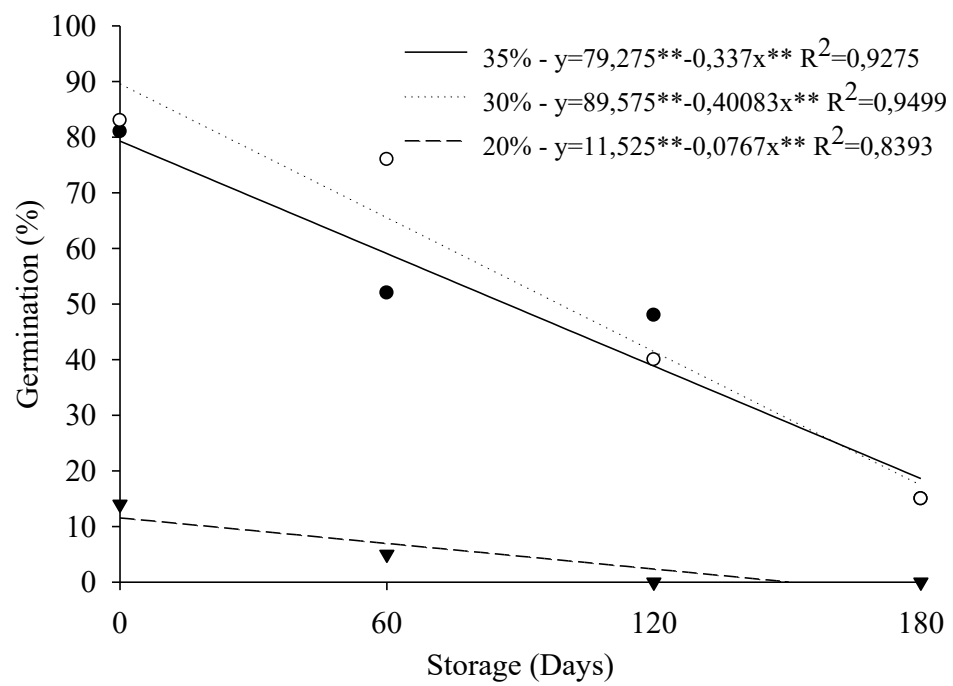

Figure 4. Mean germination values of açai seeds with different moisture contents $(35 \%-\bullet, 30 \%-\circ$ and $20 \%-\boldsymbol{\nabla})$ and stored for $0,60,120$ and 180 days.

**Significant at $1 \%$ according to the $\mathrm{T}$-test.

stored at $8{ }^{\circ} \mathrm{C}$ for 180 days, and obtained a better germination result in the seeds that had undergone drying and fungicide treatment, similarly to the observed in this work for seeds with $35 \%$ and $30 \%$ moisture contents.

The use of fungicide for controlling pathogens in recalcitrant species can be an alternative to improve storage. However, when seeds have a very high moisture content, the fungicide functionality does not last for long, as verified in this work for seeds with $35 \%$ moisture content, stored for a maximum of 60 days. After this period, fungi proliferation started to occur inside the plastic bags and during germination.

The viability data obtained from the tetrazolium test showed the same interaction as the germination test (moisture content $\mathrm{x}$ storage and moisture content $\mathrm{x}$ fungicide), with the decrease in viability during storage for all moisture contents and fungicide treatment being higher than those obtained in the control treatment. The highest percentage of viability was obtained in seeds with $35 \%$ and $30 \%$ moisture contents on day 0 (Figure 5), with mean values of $93 \%$ and $85 \%$, respectively.

Still regarding Figure 5, it is possible to note that, during the storage for 60 days, there was a sharp reduction of 37 percentage points in the viability of seeds with $35 \%$ moisture content. For seeds with $30 \%$ moisture content, the reduction was of only 8 percentage points. This viability decrease was observed in the germination data (Figure 4) throughout storage.

This accentuated reduction in viability and germination of seeds with $35 \%$ moisture content stored for 60 days may have resulted from the remoistening, as previously mentioned. On day 0 , this procedure benefitted the uniformity of germination due to the initial water absorption. However, this may have accelerated the process of deterioration during storage, once the water absorption increases the respiration rate, decreasing seed viability.

The most important alterations involved in seed deterioration are the reserves depletion; alteration in chemical composition, due to lipids oxidation and enzymes involved in deterioration and partial protein breakdown; alteration in cell membranes, due to integrity loss, increase in permeability, and membrane disorganization. Even though the deterioration rises as the water content of seeds increases, the repair mechanisms continue to work as long as there is respiration (Ibrahim and Roberts, 1983; Marcos-Filho, 2015). Some of these alterations were verified in Melanoxylon brauna, by Corte et al. (2010), and in soybean, by Carvalho et al. (2014) and Henning et al. (2010).

Table 1. Mean germination values of açai seeds with different moisture contents $(35 \%, 30 \%$ and $20 \%)$, treated (TF) and untreated (UF) with fungicide.

\begin{tabular}{ccc}
\hline Moisture contents & TF & UF \\
\hline $35 \%$ & $57 \mathrm{aA}$ & $41 \mathrm{bB}$ \\
$30 \%$ & $58 \mathrm{aA}$ & $49 \mathrm{aB}$ \\
$20 \%$ & $6 \mathrm{bA}$ & $3 \mathrm{cA}$ \\
Mean & 40 & 31 \\
\hline C.V. (\%) & \multicolumn{2}{c}{13.20} \\
\hline
\end{tabular}

C.V.-Coefficient of Variation. * Mean values followed by the same lowercase letters, in the column, or by the same uppercase letter, in the row, do not differ from each other at $5 \%$ probability by the Tukey's test. 


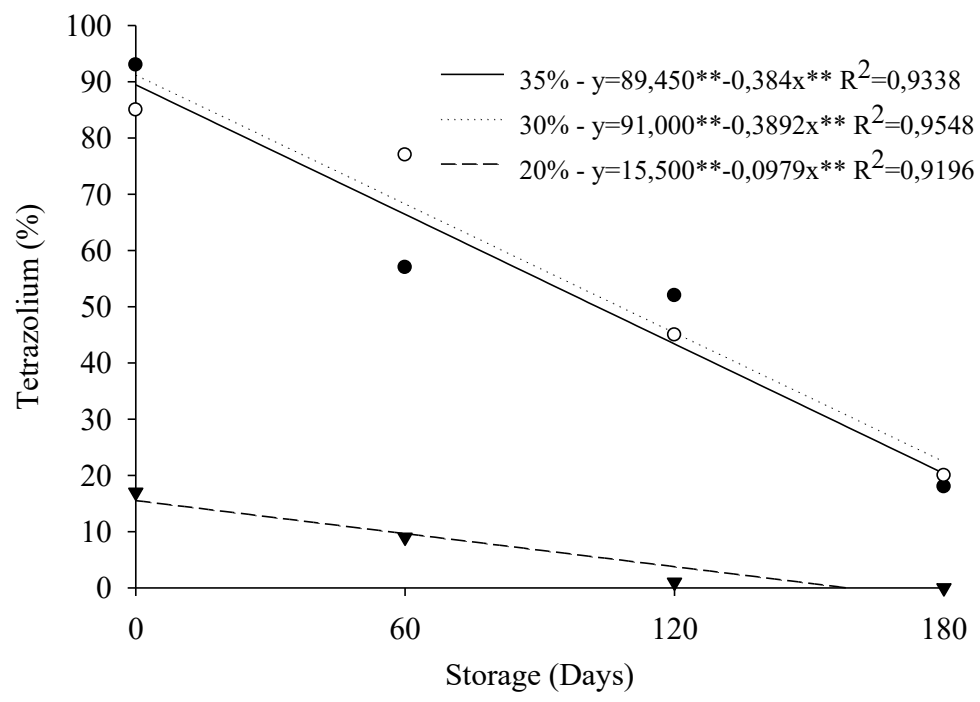

Figure 5. Mean values of tetrazolium test results of açai seeds with different moisture contents $(35 \%-\bullet, 30 \%-\circ$ and $20 \%-\nabla)$ and stored for $0,60,120$ and 180 days.

**Significant at $1 \%$ according to the $\mathrm{T}$-test.

The seeds with $20 \%$ moisture content had their viability and physiological quality affected by the drying process since the beginning of storage. Therefore, drying is not recommended for this species at this moisture content. The interaction moisture content $\mathrm{x}$ fungicide (Table 2) showed a greater viability in seeds with $35 \%$ and $30 \%$ moisture contents treated with fungicide. However, in seeds with $20 \%$ moisture content with or without fungicide treatment no difference was detected, because of the low viability of the seeds.

In the evaluation of seedling emergence (Figure 6), there was a triple interaction, according to which was possible to observe a superior performance of the seeds treated with fungicide in all three moisture contents studied. The seeds with $35 \%$ moisture content showed the greatest initial vigor, with $87 \%$ seedling emergence in those treated with fungicide, and $64 \%$ in the untreated ones. Thus, the increase in emergence is more pronounced when remoistening and fungicide treatment are used combined.

Since açai seeds have a thick tegument, water absorption occurs slowly, which may cause lack of uniformity during germination and emergence. Remoistening seeds to increase their moisture content may contribute for the formation of a more uniform set, as seen in the seedling emergence test. However, after 60 days, there was a reduction of 30 and 16 percentage points in the emergence of seedlings from seeds with $35 \%$ moisture content treated and untreated with fungicide ( $57 \%$ and $48 \%$ emergence, respectively), in comparison with the day 0 . The same was not observed in seeds with $30 \%$ moisture content, which, despite the lower initial emergence
(64\% and $56 \%$, in seeds treated and untreated with fungicide, respectively), presented a reduction of 10 and 9 percentage points $(54 \%$ and $47 \%)$ after 60 days.

After 120 storage days, the seeds with $35 \%$ moisture content exhibited statistically different results, with $47 \%$ and $34 \%$ emergence in seeds treated and untreated with fungicide, respectively. The seeds with $30 \%$ moisture content showed a significant difference in emergence, with values of $37 \%$ and $30 \%$ for treated and untreated seeds, respectively, whereas the seeds with $20 \%$ moisture content had $0 \%$ emergence, regardless of having been stored with or without the fungicide treatment.

At the end of the storage (180 days), only seeds with 35\% moisture content showed a significant difference between the emergence of seeds treated with fungicide and the untreated ones (38\% and $30 \%$, respectively). In seeds with $30 \%$ moisture content $(28 \%$ and $24 \%$ emergence in fungicide-treated and

Table 2. Mean values of tetrazolium test results of açai seeds with different moisture contents ( $35 \%, 30 \%$ and $20 \%$ ), treated (TF) and untreated (UF) with fungicide.

\begin{tabular}{ccc}
\hline Moisture contents & TF & UF \\
\hline $35 \%$ & $60 \mathrm{aA}$ & $50 \mathrm{Ab}$ \\
$30 \%$ & $62 \mathrm{aA}$ & $52 \mathrm{a} \mathrm{B}$ \\
$20 \%$ & $8 \mathrm{bA}$ & $5 \mathrm{Ba}$ \\
Mean & 43 & 36 \\
\hline C.V. (\%) & \multicolumn{3}{c}{16.12} \\
\hline
\end{tabular}

C.V.-Coefficient of Variation. * Mean values followed by the same lowercase letters, in the column, or by the same uppercase letter, in the row, do not differ from each other at $5 \%$ probability by the Tukey's test. 


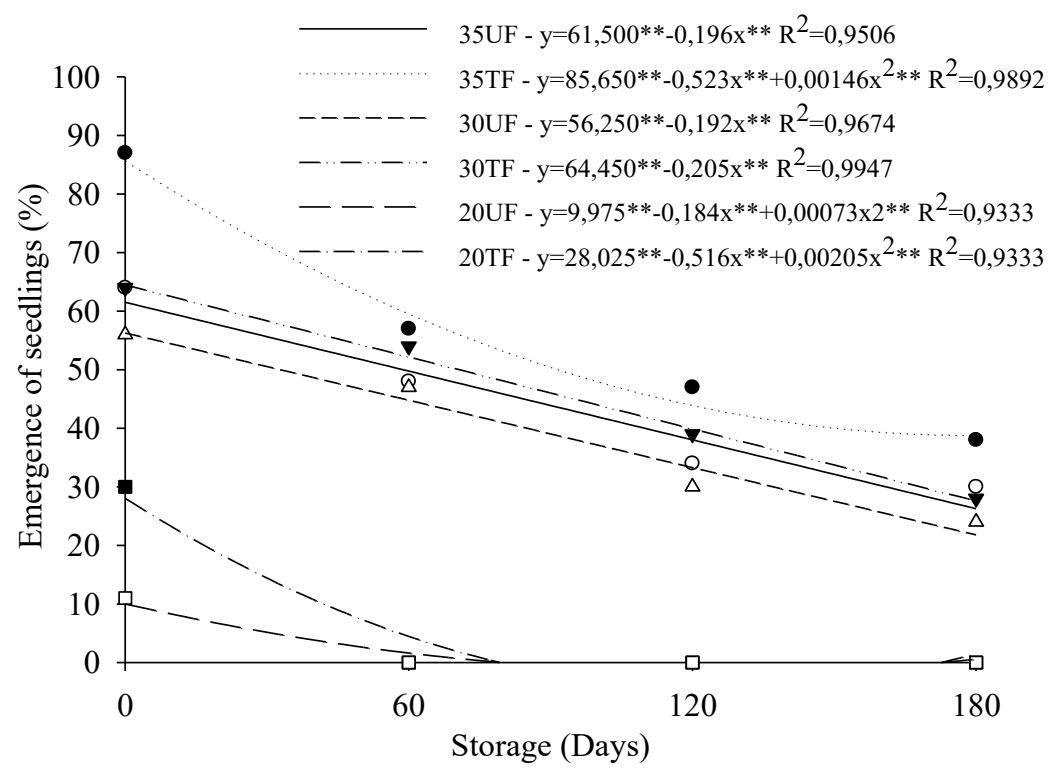

Figure 6. Emergence of seedlings from açai seeds with different moisture contents $(35 \%, 30 \%$ and $20 \%)$, treated (TF) and untreated (UF) with fungicide and stored for 0, 60, 120 and 180 days. (35UF - ०), (35TF - •), (30UF - $\Delta$ ), (30TF - $\mathbf{\nabla})$, $(20 \mathrm{UF}-\square)$ and $(20 \mathrm{TF}-\mathbf{\square})$

**Significant at $1 \%$ according to the T-test.

untreated seeds, respectively) and $20 \%$ moisture content ( $0 \%$ emergence, in both fungicide treatment conditions) such difference was not significant.

The sanitary quality of the seeds was benefitted by the fungicide treatment, thus increasing the emergence potential of the seedlings. Therefore, this is a good option for improving açai seed storage. However, seed moisture content is still a factor that affects seed quality during storage, as observed by Nascimento et al. (2007) and Nascimento et al. (2010), who also noticed a decrease in the emergence of açai seedlings, as the moisture content of the tested seeds reduced.

A point that should be emphasized is the fungicide intoxication, which can sometimes occur in the treatment of seeds. That was not observed in this study, so the dose $(250 \mathrm{~mL} / 100 \mathrm{~kg}$ of seeds) and the fungicide used (Vitavax Thiran) are recommended for açai seeds treatment. Bonome et al. (2009) worked with rubber tree recalcitrant seeds (moisture content above $30 \%$ ) treated with fungicide, but the treatment did not succeed, because the seeds suffered intoxication by the fungicide Captan.

Seedling emergence speed showed a triple interaction, and a progressive reduction in seedling emergence speed was observed throughout storage for all moisture contents assessed (Figure 7). At the stage zero, the seeds with $35 \%$ moisture content treated with fungicide showed a rate of 0.67 , while the untreated ones showed a rate of 0.44 , which represented a significant difference. The seeds with $30 \%$ moisture content with and without fungicide treatment presented rates of 0.41 and
0.40 , respectively, not differing statistically from each another. The seeds with $20 \%$ moisture content, in their turn, showed indexes of 0.19 and 0.07 for treatments with and without fungicide, respectively, which were significantly different.

Throughout the storage $(0,60,120$ and 180 days), the seeds with $35 \%$ moisture content treated with fungicide presented indices significantly higher than those of fungicide-treated seeds of the other moisture contents. Thus, the combination of fungicide and moistening helped to maintain an emergence speed higher than that of the other seeds $(30 \%$ and $20 \%$ moisture) treated with fungicide throughout the storage.

Among the seeds without fungicide treatment, those with $35 \%$ moisture content presented values statistically higher on day 0 and after 60 days of storage ( 0.44 and 0.42 , respectively) than the seeds with $20 \%$ moisture content $(0.07$ and 0.01$)$. The values of seeds with $35 \%$ moisture content after 120 and 180 days of storage $(0.31$ and 0.21$)$ were also significantly higher than in the seeds with $30 \%(0.18$ and 0.12$)$ and $20 \%$ ( 0.0 and 0.0$)$ moisture content.

The data on the emergence speed showed the reduction of the indices throughout the storage caused by seed deterioration (which is greater, in this case, because they are recalcitrant) and also due to the water content of the seeds, which is a limiting factor for this species conservation. This reduction was also verified in results of seedling emergence speed obtained by Martins et al. (2009) with seeds of Juçara dried for different periods and stored for 30 weeks in plastic 
bags at $10{ }^{\circ} \mathrm{C}$. They found a lower index in the seeds with lower moisture content, and this index reduced over storage.

The X-ray test (Figure 8) indicated a reduction of the physical quality only at the end of the storage (180 days) for the seeds with 35\% moisture content untreated with fungicide $(95 \%)$. This result can be justified by the high moisture content of these seeds, which caused fungal and bacterial proliferation, observable inside the plastic bags, and that accelerated the deterioration process. Therefore, it was verified that the damages caused by fungi proliferation were greater when the seeds presented a high moisture content and were not treated with fungicide. These damages compromised the physical structure of the seeds, causing tegument and endosperm rupture, and making them inviable.

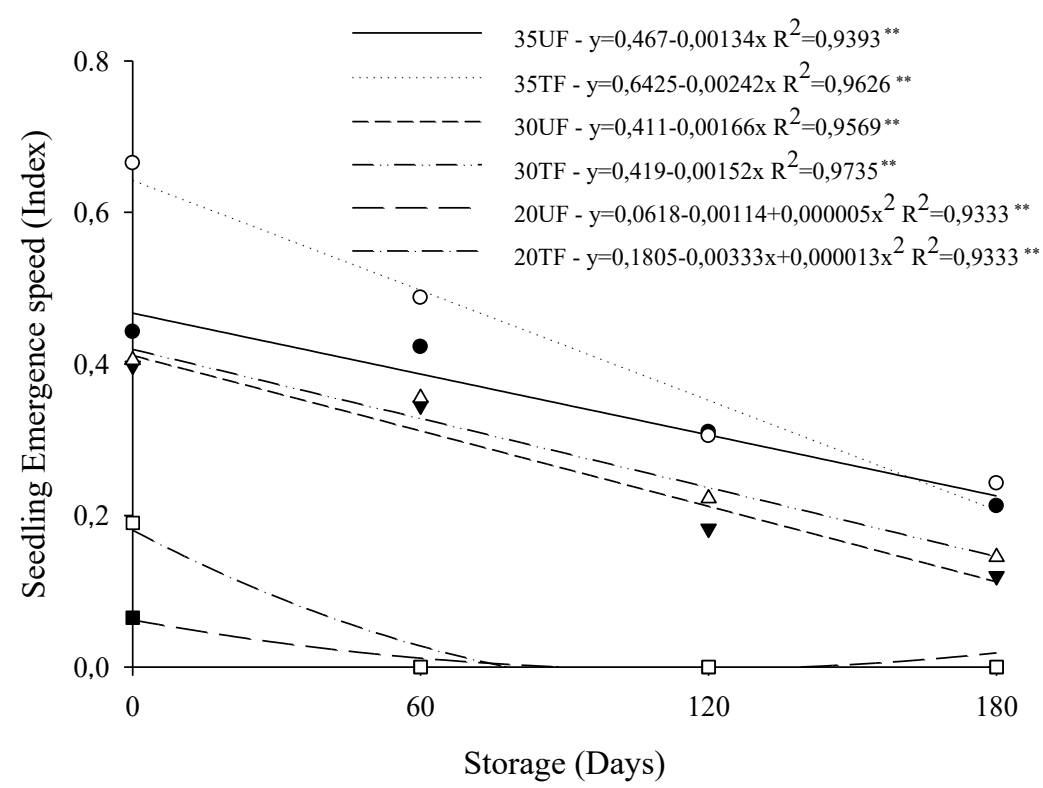

Figure 7. Seedling emergence speed in açai seeds with different moisture contents $(35 \%, 30 \%$ and $20 \%)$, treated (TF) and untreated (UF) with fungicide and stored for 0, 60, 120 and 180 days. (35UF - •), (35TF - 0 ), (30UF - $\mathbf{\nabla}),(30 \mathrm{TF}-\Delta$ ), (20UF - - - ) e (20TF - $\square)$.

**Significant at $1 \%$ according to the T-test.

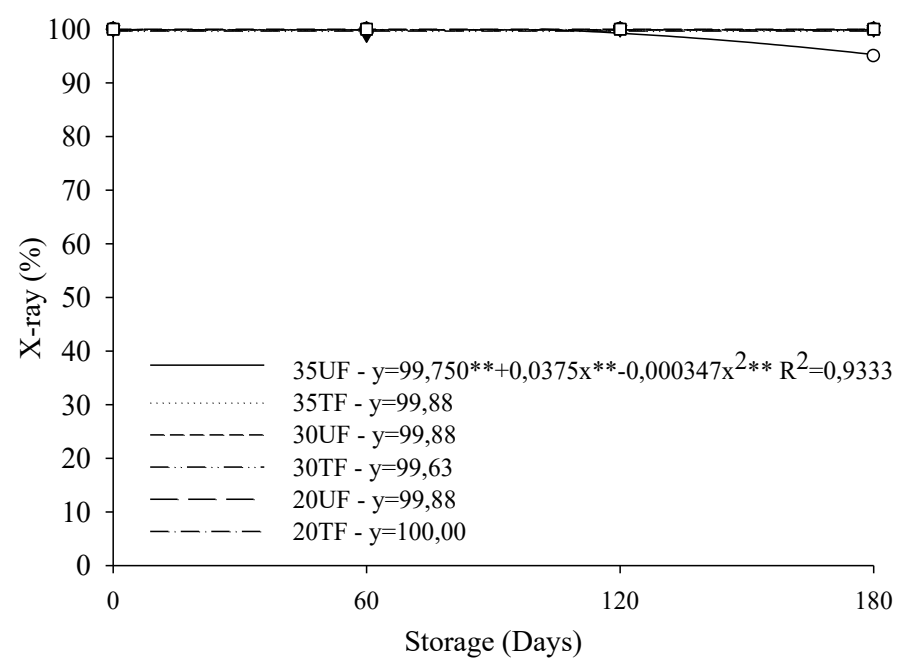

Figure 8. Mean of X-ray results (whole seeds) in açai seeds with different moisture contents (35\%, 30\% and 20\%), treated (TF) and

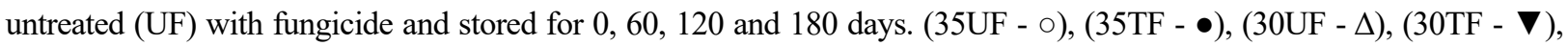
$(20 \mathrm{UF}$ - $\square)$ e (20TF - - $)$ ).

**Significant at $1 \%$ according to the T-test. 
In summary, it was observed that, among the drying treatments $(30 \%$ and $20 \%)$, the seeds with $30 \%$ moisture content remained viable. The storage in plastic bags for 180 days in a natural environment was not enough to maintain the physiological quality of the seeds, and in order to obtain a germination rate above $50 \%$, the recommended storage time limit in these conditions is 60 days.

The seeds with $35 \%$ and $30 \%$ moisture contents treated with fungicide presented the best physiological quality results when compared to the treatments without fungicide. Therefore, fungicide treatment is recommended for this species.

\section{Conclusions}

Açai seeds with $35 \%$ and $30 \%$ moisture contents treated with fungicide have a better physiological quality in relation to the seeds untreated with fungicide.

Storage longer than 120 days reduces seed germination to values below $50 \%$, regardless of whether they are treated or untreated with fungicide, but the reduction is greater for seeds without the fungicide treatment.

The fungicide treatment is efficient in controlling fungi up to 180 days of storage in açai seeds with $30 \%$ and $20 \%$ moisture contents, and up to 60 days of storage in seeds with $35 \%$ moisture content.

\section{References}

BALARDIN, R.S.; SILVA, F.D.L.; DEBONA, D.; CORTE, G.D.; FAVERA, D.D.; TORMEN, N.R. Tratamento de sementes com fungicidas e inseticidas como redutores dos efeitos do estresse hídrico em plantas de soja. Ciência Rural, v.41, n.7, p.1120-1126, 2011. http://www.scielo.br/scielo.php?script=sci_ arttext\&pid=S0103-84782011000700002

BARBEDO, C.J.; MARCOS-FILHO, J. Tolerância a dessecação de sementes. Acta Botânica Brasileira, v.12, n.2, p.145-164, 1998. http://www.scielo.br/pdf/abb/v12n2/v12n2a05

BERJAK, $\mathrm{P}$. The role of microorganisms in deterioration during storage of recalcitrant and intermediate seeds. In: OUÉDRAOGO, A.S.; POULSEN, K.; STUBSGAARD, F. (Ed.). Intermediate/recalcitrant tropical forest tree seeds: proceedings of a working on improved methods for handling and storage of intermediate/recalcitrant tropical forest tree seeds. Rome: IPGRI, 1995. p.121-126.

BONOME, L.T.S.; OLIVEIRA, L.E.M.; GRACIANO, M.H.P.; MATTOS, J.O.S.; MESQUITA, A.C. Influência do tratamento fungicida e da temperatura sobre a qualidade fisiológica de sementes de Seringueira durante o armazenamento. Agrarian, v.2, n.5, p.97-112, 2009. http://ojs.ufgd.edu.br/index.php/agrarian/article/ viewFile/808/488
BRASIL. Ministério da Agricultura, Pecuária e Abastecimento. Regras para análise de sementes. Ministério da Agricultura, Pecuária e Abastecimento. Secretaria de Defesa Agropecuária. Brasília, DF: MAPA/ACS, 2009. 395p. http://www.agricultura.gov.br/arq_editor/ file/2946_regras_analise_sementes.pdf

BRASILEIRO, B.G.; SILVA, D.F.P.; BHERING, M.C.; MOURA, E.B.B.; BRUCKNER, C.H. Qualidade fisiológica de sementes de Nêspera armazenadas em diferentes embalagens. Revista Brasileira Fruticultura, v.Especial, n.1, p.686-691, 2011. http://www.scielo.br/ pdf/rbf/v33nspe1/a96v33nspe1.pdf

CARVALHO, E.R.; MAVAIEIE, D.P.R.; OLIVEIRA， J.A.; CARVALHO, M.V.; VIEIRA, A.R. Alterações isoenzimáticas em sementes de cultivares de soja em diferentes condições de armazenamento. Pesquisa Agropecuária Brasileira, v.49, n.12, p.967-976, 2014. http://seer.sct.embrapa.br/index.php/pab/article/ view/18954/12838

CARVALHO, N.M. A secagem de sementes. 2.ed. Jaboticabal: FUNEP, 2005. 184p.

CORTE, V.B.; BORGES, E.E.L.; LEITE, H.G.; PEREIRA, B.L.C.; GONÇALVES, J.F.C. Estudo enzimático da deterioração de sementes de Melanoxylon brauna submetidas ao envelhecimento natural e acelerado. Revista Brasileira de Sementes, v.32, n.1, p.083091, 2010. http://www.scielo.br/pdf/rbs/v32n1/v32n1a10.pdf

FERREIRA, D.F. Sisvar: a computer statistical analysis system. Ciência e Agrotecnologica, v.35, n.6, p.1039-1042, 2011. http://www.scielo.br/ scielo.php?script=sci_arttext\&pid=S1413-70542011000600001

GUEDES, C.; SEGUNDO JUNIOR, O.; SOUZA, A.R.S.; SOUZA, D.G.; SOUZA, D.R.D.S.; CUNHA NETO, M.P.D.; LINHARES, R.L. Quebra de dormência em sementes de açaí. Anais Programa Ciência na Escola, v.2, n.1, p.14-16, 2014. http://gpaaa.inpa.gov.br/ index.php/RCE/article/view/217/124

HENNING, F.A.; MERTZ, L.M.; JACOB JUNIOR, E.A.; MACHADO, R.D.; FISS, G; ZIMMER, P. D. Composição química e mobilização de reservas em sementes de soja de alto e baixo vigor. Bragantia, v.69, n.3, p.727-734, 2010. http://www.redalyc.org/ $\mathrm{html} / 908 / 90816059026 /$

IBRAHIM, A.E.; ROBERTS, E.H. Viability of lettuce seeds: I. survival in hermetic storage. Journal of Experimental Botany, v.34, n.142, p.620-630, 1983. https://www.jstor.org/stable/23690685

KRUGNER, T.L.; AUER, C.G. Doenças dos eucaliptos. In: KIMATI, H.L.; BERGAMIN FILHO, A.A.; CAMARGO, L.E.A.; REZENDE, J.A.M. (Ed.). Manual de Fitopatologia: doenças das plantas cultivadas. Viçosa, MG: Ceres, 2005. p. 319-332.

MAGUIRE, J. D. Speed of germination-aid in selection and evaluation for seedling emergence and vigor. Crop Science, v.2, n.1, p.176-177, 1962. https://dl.sciencesocieties.org/publications/cs/ abstracts/2/2/CS0020020176/

MARCOS-FILHO, J. Fisiologia de Sementes de Plantas Cultivadas. 2ed. - Londrina, PR: ABRATES, 2015. 660p. 
MARTINS, C.C.; BOVI, M.L.A.; NAKAGAWA, J.; MACHADO, C.G. Secagem e armazenamento de sementes de Juçara. Revista Arvore, v.33, n.4, p.635-642, 2009. http://www.scielo.br/scielo. php?script $=$ sci_arttext\&pid=S0100-67622009000400006\&lng=en $\&$ nrm $=$ iso\&tlng $=$ pt

MITTAL, R.K. Mycoflora of recalcitrant tree seeds and its effects on germination and storability. Journal of Mycopathological Research, v.41, n.1, p.127-134, 2003. http://direct.bl.uk/bld/placeorder. do? uin $=156077513$ eetoc $=$ rnefrom $=$ searchengine

NASCIMENTO, W.M.O.; CICERO, S.M.; NOVEMBRE, A.D.L.C. Conservação de sementes de Açaí (Euterpe oleracea Mart.). Revista Brasileira de Sementes, v.32, n.1, p.24-33, 2010. http://www.scielo. br/pdf/rbs/v32n1/v32n1a03.pdf

NASCIMENTO, W.M.O.; MORAES, M.H.D. Fungos associados a sementes de Açaí: efeito da temperatura e do teor de água das sementes durante o armazenamento. Revista Brasileira de Sementes, v.33, n.3, p.415-425, 2011. http://www.scielo.br/pdf/rbs/v33n3/04.pdf

NASCIMENTO, W.M.O.; NOVEMBRE, A.D.L.C.; CICERO, S.M. Consequências fisiológicas da dessecação em sementes de Açaí (Euterpe oleracea Mart.). Revista Brasileira de Sementes, v.29, n.2, p.38-43, 2007. http://www.scielo.br/scielo.php?script=sci_ arttext\&pid=S0101-31222007000200006
OLIVEIRA, C.F.; OLIVEIRA, D.C.; PARISI, J.D.; BARBEDO, C.J. Deterioração de sementes de espécies brasileiras de Eugenia em função da incidência e do controle de fungos. Revista Brasileira de Sementes, v.33, p.520-532, 2011. http://www.scielo.br/scielo. php?script $=$ sci_arttext\&pid=S0101-31222011000300015

PARISI, J.J.D.; BIAGI, J.D.; BARBEDO, C.J.; MEDINA, P.F. Viability of Inga vera Willd. subsp. affinis (DC.) TD Penn. embryos according to the maturation stage, fungal incidence, chemical treatment and storage. Journal of Seed Science, v.35, n.1, p.70-76, 2013. http://www.scielo.br/pdf/jss/v35n1/10.pdf

PEREIRA, C.E.; OLIVEIRA, J.A.; ROSA, M.C.M.; KIKUT, A.L.P. Armazenamento de sementes de braquiária peletizadas e tratadas com fungicida e inseticida. Ciência Rural, v.41, n.12, p.2060-2065, 2011. http://www.scielo.br/pdf/cr/v41n12/a19011cr5448.pdf 